\title{
Topology and the Web of Informal Economy: Case study of kakilima and its twisted networks in the market of Kabayoron Lama. Jakarta
}

\author{
Triatno Yudo Harjoko , Joko Adianto \\ Department of Architecture, \\ Universitas Indonesia, Indonesia \\ gotty@eng.ui.ac.id
}

\begin{abstract}
Kakilima, i.e., generic informal urban economy, has been both urban problems and blessings in Indonesia. They are omni-present and an 'eyesore'. They are part of structuration process of the society - in which they are produced and reproduced - including its economy. The researchistodiscloseeconomicbehavior andactivities inspatial terms. The findings suggest that they are convoluted both in kinds and may embed within the formal one.
\end{abstract}

Keywords windows; illumination level; residential building; occupant's perception.

eISSN 2514-751X @ 2018. The Authors. Published for AMER ABRA cE-Bs by e-International Publishing House, Ltd., UK. This is an open-access article under the CC BY-NC-ND license (http://creativecommons.org/licenses/bync-nd/4.0/). Peer-review under responsibility of AMER (Association of Malaysian Environment-Behaviour Researchers), ABRA (Association of Behavioural Researchers on Asians) and cE-Bs (Centre for EnvironmentBehaviour Studies), Faculty of Architecture, Planning \& Surveying, Universiti Teknologi MARA, Malaysia.

DOI: https://doi.org/10.21834/aje-bs.v3i6.248 


\subsection{Introduction}

Kakilima is a short term of Pedagang kakilima or literally street vendors which refers to generic informal urban economy such as ambulant traders, vendors, and all kinds of permanent establishment of informal business in illegal places. The word kakilima is derived from the dimension of side walk, that is, five feet. Formally, we call it sidewalk trotoar (from French word Trottoir - path, sidewalk). Trotoar and kakilima have been a crucial urban issue in big cities in Indonesia. Both are an awry situation. Trotoar is a public space that forbids private engagement while the existence of kakilima represents informal private enterprise.

Urban problems and issues related to kakilima (are) socio-political Indonesian society, like other societies from developing countries, is constituted by a so-called binary or dual-society and its economic activity: modern/formal/capitalist versus traditional/informal/bazaar. They compete and contest over scarce urban space. With regard to planning practices, planners are biased toward global knowledge, theories of cities in which they perceive and conceive urbanism as a Global-Western (Harjoko, 2002, 2008, and 2009). As a result, kampung settlement, kakilima have been seen as an eyesore and, 'unreal.' While kakilima has never been properly allocated for its life-cycle space in the urban setting, it has been exacerbated by the Government Regulations of permissiveness that does not strictly stipulate trotoir or sidewalk as a public use, secure it from private use and let alone development control against such infringement.

The research seeks to unravel deep structure of so called informal sector in the urban areas with a particular reference to Pasar Kebayoran Lama, Jakarta. Such a structure is conceived in terms of its spatial formation, production and reproduction.

\section{Research Enquiries}

Understanding urban architecture simply from physical appearance (material culture) of the built environment may overlook the deep structure of the city, how it is built or evolved - the lived space. This is crucially the case in a country like Indonesia which is constituted by the dual society, i.e., modern-capitalist/traditional- bazaar, or, formal/informal sectors. Their respective structuration process evolves and competes over scarce urban space. In many cases, they are mutually exclusive in terms two-dimensional space. However, there seems to be a 'spatialrelation' among them that could not be seen visually or by our naked eyes. This relation can be conceived as meta-space that resides in human mind such as that of chess players who visualize the movement of the pieces.

Based on such understanding, the question will be what is the role of kakilima in the city? Why they are ubiquitous and persistent in the city? How could we uncover a seemingly disorder lived-space of kakilima in this context?

Jeff E. Malpas (2004: 44) quotes Ernst Mach (1906: 32) in discussing the difference between 'physiological' and 'geometric' space stated that, "Of cardinal and greatestimportance to animals are the parts of their own body and their relations to one another ... Geometric space embraces only the relations of physical bodies to one another, and leaves the animal body in this connection altogether out of account". Malpas argues that "understanding the way in which living creatures find themselves 'in' space, both in relation to their bodies and to one another, requires more than just a concept of space as articulated within physical theory." The question is 
then, how could we observe the web of relations that exist in sub-teranian level (rhizome) or a meta-space within the mind of the actors?

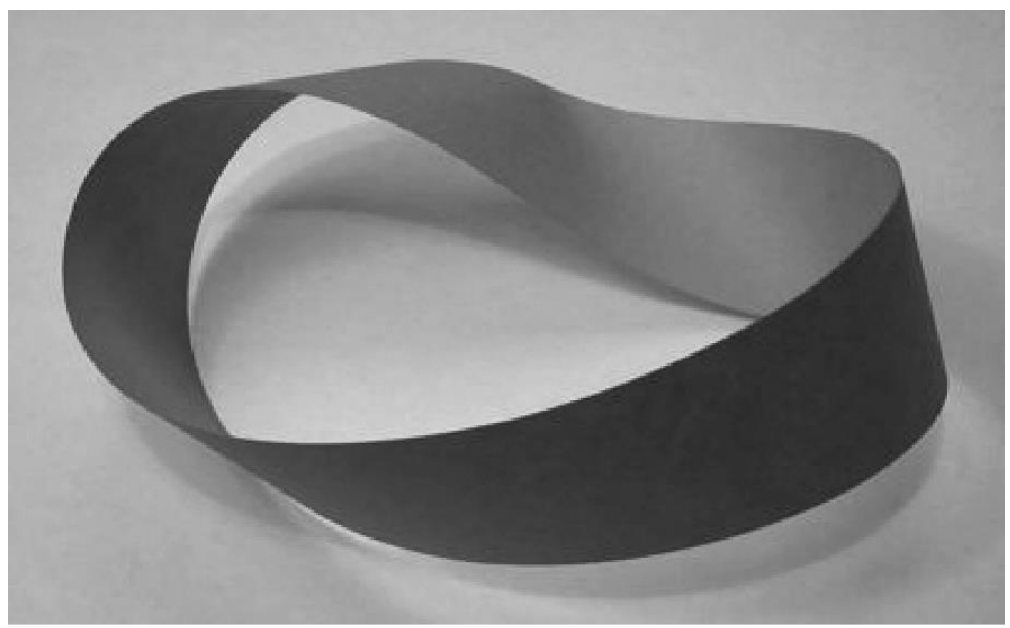

Figure 1: Mobius Strip - Twisted Space

(Source: http://mathforum.org/mathimages/imgUpload/thumb/Mobius_strip.jpg/400px-Mobius_strip.jpg, 02.02.11)

Jean-Michel Kantor (2005) states that "[t]opology ... is a (mathematical) way of conceiving of TOPOS: the place, the space, all space, and everything included in it". He evokes a few examples of forms and spaces which stimulate for all those interested in the concept of space, architects in particular. In topology, we no longer distinguish between two figures, two spaces, if you can pass from one to the other by means of a continuous deformation - with neither leap nor cut. Mobius strip - a non-orientable surface as opposed to an orientable surface that has two sides - is an excellent example of a twisted space. The term space topology here will refer to the way we perceive and conceive the lived-space of trotoar used by kakilima in urban areas in Indonesia: from which it 'is' closely related to other formal commercial activities in the surroundings. Relationship between them cannot be discernible as a simple two dimensional space of existence.

Anthony Giddens (1984) argues that a constitution of society could be deeply understood by means of its production and reproduction of the society - or he calls it structuration. Indonesian society is constituted by a duality of society, that is, modern/capitalist and traditional/bazaar. They produce and reproduce its respective societies. In architectural terms and urban context they compete over space in a city. The problem has been that planners and decision makers are more supportive towards the dominant capitalist one. This creates urban closures and then, as a consequence, causes urban usurpation by the underprivileged majority (Harjoko, T.Y., 2002). 


\subsection{Methodology}

The research concerns humanly urban form and seeks to understand the space topology or deep structure of enormous existence of kakilima in the pasar or market of Kebayoran lama in the southern part of Jakarta. The main objective the research is to disclose a 'virtual map' or space topology of kakilima in the market of Kebayoran lama. The conspicuous existence of kaki-lima has been in the vicinity of pasar or conventional market, where formal economy is regulated and allocated by the local government. It will focus on the production and reproduction of space of kakilima that seems to be dynamic in terms of various different forms of economic engagements and actors involved in space-time - round the clock. In this mode, spatial structure may manifest in multi-layered or dimensions or topological.

It is a grounded research from which theses or theories are put together at the end of investigation. Respondents among pedestrians are taken at random. Interviews are carried out among kakilima and formal shop owners. They are 'actors' that may conceive different image of a space and supposedly have critical decisions on the consumption or usage of a critical space around the pasar. Quantitative analysis is used to indicate the magnitude of the questions under investigation. Correlation analysis is carried out between variables. Random sampling is carried out to pedestrian at different strategic points on working days and week-end (1680 respondents - this is taken in four consecutive weeks); kakilima of various commodities (10 respondents); formal shops ( 25 respondents).

\subsection{Results and Analaysis Statistical Significance}

Due to a limited space, all statistical analyses cannot be presented here. However, results have shown that there is a significant difference of correlation between pedestrian and kakilima that is static or fixed in a place and that of ambulant or dynamic (samples are taken twenty-four hour week-days and in the week- end).

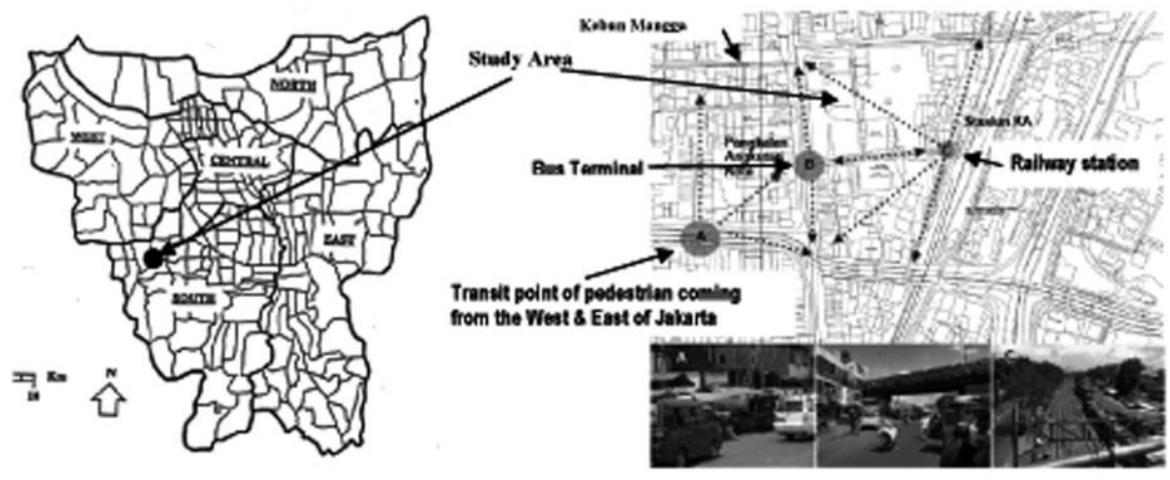

Figure 2: Map of Jakarta and study area

Figure 3: Study area: strategic points where pedestrian is generated 
Fixed establishment of stalls, esp., vegetables, which are occupying space around Railway Terminal, under the Fly-over road, have negative correlation with pedestrian. Vegetable sellers increase in number during the crack of dawn, while at the same time pedestrians are decreasing. Quite the contrary, ambulant traders and pedestrians have shown positive correlation of their existence from the early in the morning up to the night and dawn. Both show a maximum number in the early of the morning and gradually decrease during the night (Appendix A).

\subsection{Types of goods: durable goods}

Research has shown that there are similarities of the types of goods sold among parties questioned, that is, kakilima on the trotoar and the formal retail shops. Based on the in-depth interview with kakilima as well as the shop owners it is revealed that they seem to 'collaborate' to sell the merchandise from supplied by the shops. While the shops sell the commodities wholesale at a lower price, quite often the kakilima prepays partially the merchandise to the shops and it then sells at higher price. In fact, lapaks (literally floor mat), or a set of unit to put or display goods of the kakilima, are located just in front of the shops of similar goods. In other words, the shops make use of and existence of kakilimas to exercise something like 'multi-level' marketing. In such 'cooperation', an unwritten agreement of this cooperation is made between kakilima and shop. Despite such an agreement, kakilimas are free to have a different deal with other shops.

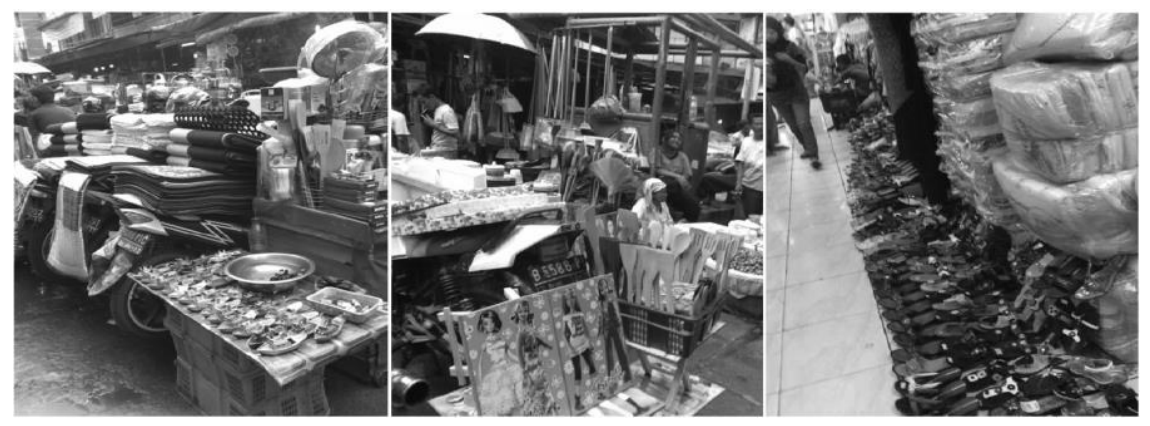

Figure 4: Various commodities of durable goods

\subsection{Types of goods: food and beverage and agriculture produce}

Kakilima selling food and beverage in many cases concentrate on the strategic nodal points, such as crossroads close to the pasar or market. This space to the kakilima is space that is strategic to 'intercept' pedestrian moving around from and to pasar, to the pedestrian buyers it is also strategic location to get something to buy while they are moving to and fro. In comparison with the durable goods such as garments, bags and other similar commodities, stalls of food and beverages are visited at the time people need have breakfast, lunch or dinner. Consumers come from various different social strata. The vendors or ambulant traders 
take strategic locations such as in nodal points where pedestrian stop or stand by the sidewalk waiting public transports. They sell various kinds of fast-food so the consumers do not have to wait long and 'eat-in'. In comparison to stalls selling durable goods, the patrons of these commodities are at random. Buyers stop by almost without any purpose or intention to get something to buy. When they stop by they take quite sometime to look for goods and for the best available price. Fact has shown that kakilimas selling food and beverage assume customers in everyday willing to come when they need something to eat or drink. This explains why kakilima of this type are competing scarce space in almost everywhere around the pasar or traditional market.

Space-time determines the pattern of various kakilimas gathered and located. Asongan, or ambulant kakilimas are the most mobile ones. They intercept pedestrians and move wherever the crowds are concentrated. Cases have shown that at 6.00 am cigarette asongans gathered at the crossroad and Kebun Mangga Street. These locations at this time being the nodes of modal-split of transport are packed with pedestrian coming from residential areas around the Pasar Kebayoran Lama. From 8.00 to 9.00 am, these asongans move to Railway Station in which passengers are getting off the train coming from Bekasi and Tanah Abang. From 9.00 to 12.00 am they move into and around Pasar Kebayoran Lama. The pasar is open and customers are coming in. In the afternoon, between 12.00 to 2.00 afternoon, they move toward available cross roads around the pasar. This is lunch time in which employees, drivers of pubic transport come for lunch. From 5.00 to $8.00 \mathrm{pm}$ these asongans move back to Jalan Kebun Mangga and cross roads because pedestrians are coming back from their workplace and going back home

Kakilimas selling fruits crowd the space on trotoar at southern side of the fly-over bridge where public transports coming from Blok $\mathrm{M}$ in Kebayoran to Tangerang in the periphery of Jakarta. People buy fruit on the way home, as dessert after dinner. The peak transaction of this commodity occurs at half past four to seven o'clock in the afternoon. In late evening about ten o'clock, pickups that transport raw agriculture produces arrive. The lack of proper space for unloading causes problem for unloading the products. They simply unload and put these commodities along the trotoir close to the pasar Kebayoran Lama. This creates traffic congestion in the area. Since pasar is closed at $9.30 \mathrm{pm}$, the new arrival of agriculture produces cannot directly be transported into the pasar. This compels sellers to open lapaks along the trotoar as informal activities. It emerges as a pasar tumpah or overspill-instant market. This situation does not seem unanticipated by the sellers because, in fact, the buyers come at night until midnight in significant numbers. These buyers are those who own restaurants, catering industries and even mobile vegetable sellers (tukang sayur keliling) that sell around the residential areas nearby. The respondent claims that they buy fresh vegetable at night transported directly from the rural areas, no sun light that burns. This explains why the numbers of kakilima selling vegetables are massively packed in the area at night. 


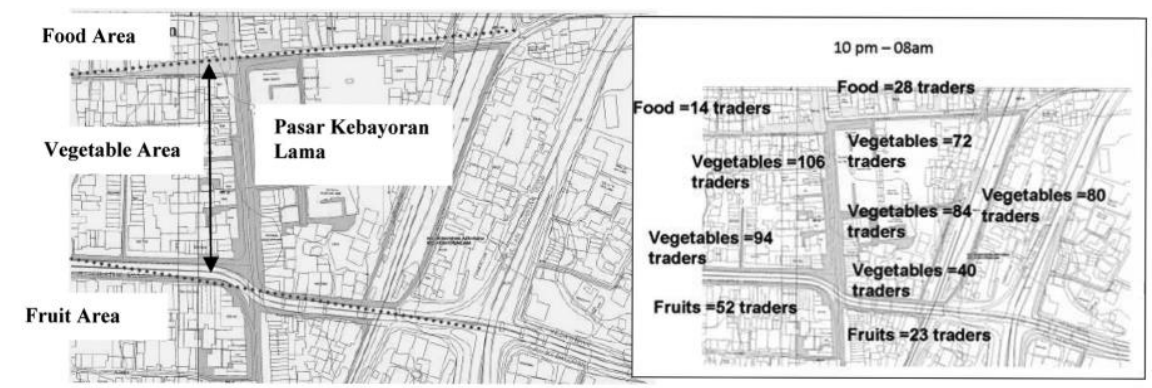

Figure 5: Different groups of kakilima: Their numbers of each clustering location

\subsection{Informal economy}

Kakilima activities involve some kind of social network. It includes distribution, supplies, and services including protection or security. In-depth interview with kakilima respondents has shown that lapaks and baskets are not produced by themselves but by preman or thugs that also give protection to them. Materialfor building lapaks are supplied by scavengers or coolies collecting material from a demolished building. In return kakilima pays a certain amount of money to preman for the services including providing lapak, security, and waste collection. The money is paid by every kakilima in accordance with their respective time-shift. Statistics indicate that average working hour is about ten hours per day. The next shift, the space will be allocated for their friends, relatives and even the member of their family.

Local Socio-political Web. Another finding within this complex web is the involvement the head of Rukun Tetangga (RT) or Household Administrative Unit as well as of Rukun Warga $(R W)$ or Neighborhood Administrative Unit (One RW administers about twelve to fourteen RTs). The carts for transporting goods are stored along the gang or alleys by the permission of the formal local or community administrative bodies. In this web, preman also give money to these heads of the community. Furthermore, unemployed youngsters and adults are also given opportunities to take in transporting goods from one location to another. Covert connection between kakilima economy and especially the heads of RT and RW has given a political blessing for them to secure their position as local leader. It may explain why kakilima has persevered and been omnipresent in the big cities, especially Jakarta.

Housing Provision for the Poor. Most kakilima selling at day time in this study are coming from outside Jakarta, that is, from Serang and Tangerang, West Java. This situation then creates demand for housing provision in the area. Local land lords in the kampung immediately responded over the demand in the development of rumah petak - small rowhouses of about twelve square meters area each. The rent of each house with communal toilet is Rp 400,000 (US \$ 45) per month. This unit is collectively rented and shared by around eight to twelve vendors. Mathematically it is unimaginable that this number of people will sleep in a small area. In fact, they use the housing unit on shift in accordance with the time of each group to do business. Each group of three to four people will stay or do business from home.

Demand for Electricity. Kakilima, especially those selling vegetables and fruits, get the 
illegal supply electricity at night from those worked in pasar management and an individual from PLN (State Electricity Body). Kakilima that sells vegetables and fruit comes to the area at night. Therefore, charges over the electricity are collected also in the evening between eight to ten o'clock. Kakilimas take the lapaks that have been prepared including lighting by preman. In some cases, the preman provides cable and fixtures while the kakilimas bring their own bulbs. In the case of kakilimas located in front of formal tokos or shops, water and electricity are provided by the tokos. Owner of toko benefits from this mutual service from which kakilima may also take care the toko especially during the night time, and at the same time kakilima pay preman for their security.

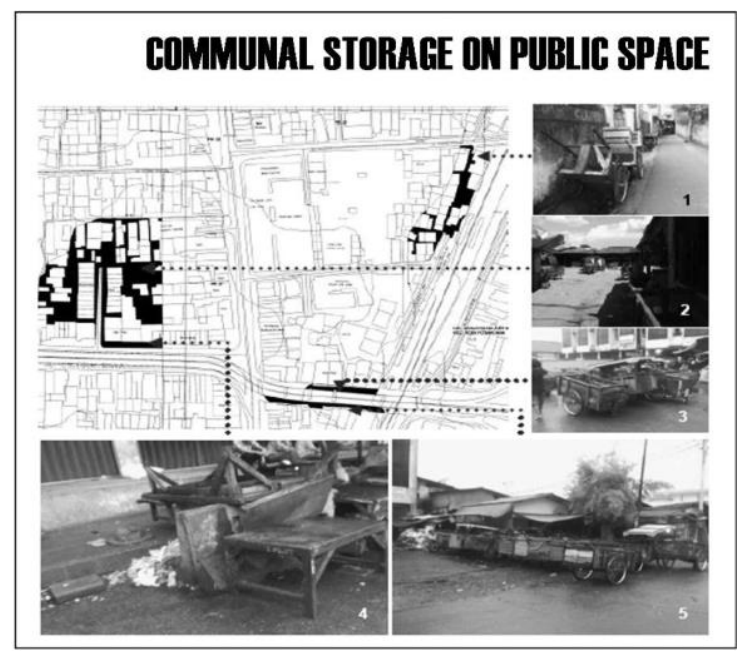

Figure 6: A number of pockets for storage on public space

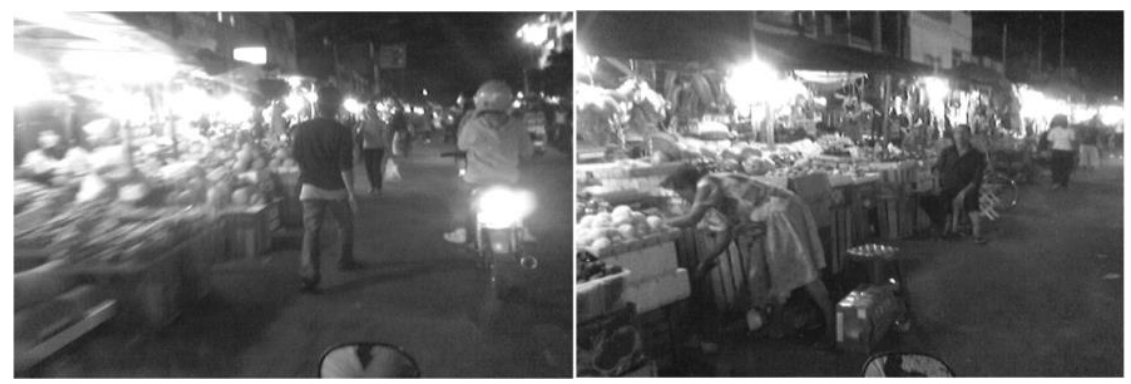

Figure 7: The emergence of pasar tumpah or instant-overspill market at night until dawn 


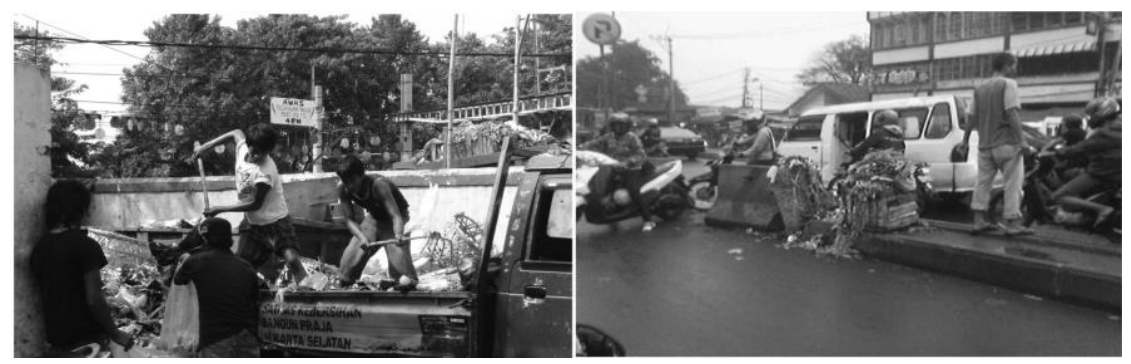

Figure 8: Waste disposal locations: Left figure - formally designated by the local government; Right: temporary location that does not seem to be prevented by the local government. Young labor is being hired to solve the waste management.

Waste Collection. Despite the formal services which come from local government office, they also invite unemployed people in the neighboring areas. Waste produced by pasar is dumped in available locations around it. Vegetable sellers put their waste in the road median. This seems to be comfortable locations for collection. In the morning at seven o'clock garbage truck of Sanitary Department of the DKI Jakarta collects waste from the designated locations.

\subsection{Conclusion}

The main issue is equal access for urban space in this context economic space. While space allocated in the practice urban planning is bias toward formal capitalistic economy, has been marginalized and ignored or even denied resulting in the usurpation of what ever urban space may seem available for them. This has further been complicated. It implies double standard over the use of trotoar as well as also permissive stance of the government. On the one hand, life-cycle of formal economy is imposed by the formal law and regulation; on the other, lifecycle of informal sector evolves round the clock in conjunction with the life-cycle of the lowincome, especially in the economic activity. In this mode, urban space has been twisted, distorted according to the dynamic of movement of pedestrian and different actors that involve in the 'game-play' around the pasar Kebayoran Lama.

In the case of Pasar Kebayoran Lama, it has been demonstrated that the marginalized kakilima defies the law of the place enforced by the local government excluding them from urbanization process. Process usurping urban space is not as simple as we can see with our naked eye. It seems chaotic, disorder and 'dirt.' The trajectory of action exists in meta-space, that is, in mind of the actors involved. It is not two-dimensional space. It is topological. Space of action has been flipped, twisted in terms of tenure. It is unclear who controls, holds or sustains the property. Trajectories of complex activities seem to appear in the minds of kakilima, shop owners, preman, official security of the pasar, local leader, and unemployed youngsters, but 
cannot be visually captured by our naked eye. This meta-space 'exists' in the mind like that of chess players who think the movement of the piece in a thousands of combination.

\section{References}

De Certeau, M. (1984). The Practice of Everyday Life. Berkeley, Los Angeles and London: University of California Press.

Giddens, A. (1984). The Constitution of Society. Berkeley and Los Angeles: University of California Press.

Harjoko, T. Y. (2002). A City as a Practice of Social Closure of Exclusion and Usurpation, in International Association for the Study of Traditional Environments, Traditional Dwellings and Settlements. Working Paper Series, 151, 29-60

Harjoko, T. Y. (2008). 'Hyper-versus Involuted-Tradition: Urbanism in Indonesia'. Proceeding 4th International Seminar on Vernacular Settlement. Ahmedabad, India, February 14-17, 2008

Harjoko, T. Y. (2009). Urban Kampung: Its Genesis and Transformation into Metropolis, with particular reference to Penggilingan Jakarta. VDM Verlag Dr. Müller.

Kantor, J. (2005). 'A Tale of Bridges: Topology and Architecture'. Nexus Network Journal $-7(2)$

Mach, E. (1906). Space and Geometry in the Light of Physiological, Psychological and Physical Inquiry. Chicago: Open Court.

Malpas, J. E. (2004). Place and Experience: A Philosophical Topography. Cambridge University Press.

Wheatley, P. (1963). Nagara and Commandery. Origins of the Southeast Asian Urban Traditions, Department of Geography, Research Paper Nos. 207-208 (Double Number), The University of Chicago. 
Harjoko, T.Y., \& Adianto, J. / Asian Journal of Environment-Behaviour Studies (ajE-Bs), 3(6) Jan / Feb 2018 (p. 179-189)

Appendix: Correlation Diagram Between Kakilma and Pedestrian: Weekdays and Weekend

PEIESTRIAN: STATIC VENDOR

SIMPANG ARTERE WEEXDAYS KEBUN MANGEA: WEEXDAYS
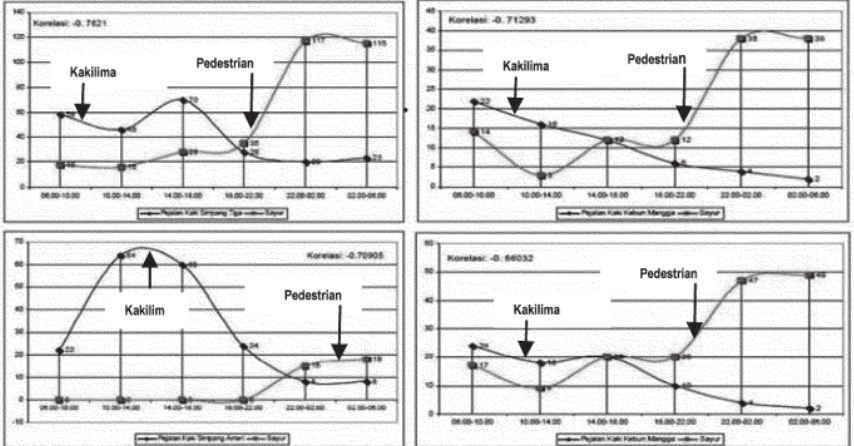

SMPANG ARTERI WEEKEND KEBUN MANEEA: WEEKEND

Diagram A:

Negative correlation of pedestrians and kakilimas in the Fixed Establishment of Vendors Main Crossroads (Transit Points) \& Kebun Mangga Street

PEDESTRIAN : AMBULANT VENDORS

MAIN GROSBROADS: WEEXDAYS KEBUN MANBEA: WEEXDAYS
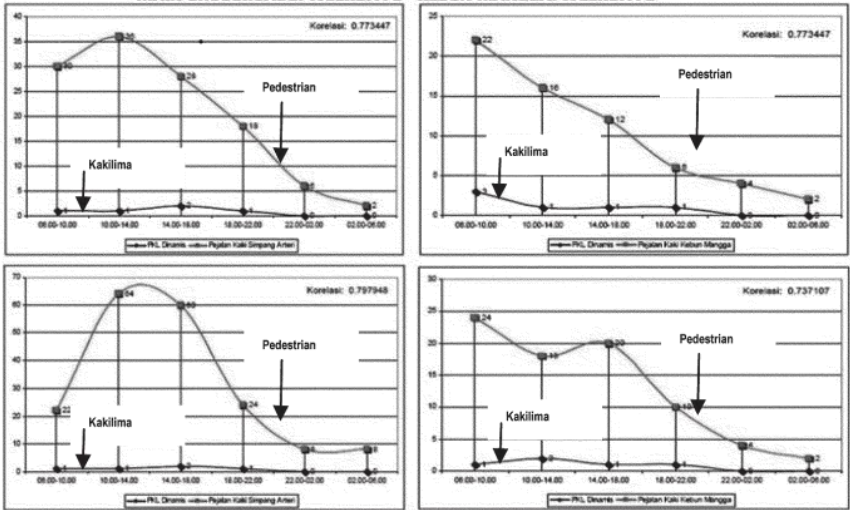

MAN GROSSROADS: WEEXEND KEBUN MANGEA: WEEXEND

Diagram B:

Positive correlation of pedestrians and kakilimas of he mobile vendors) Main Crossroads (Transit Points) \& Kebun Mangga Street 